\title{
Suppression of host defences by Aspergillus fumigatus
}

\author{
MAURA D ROBERTSON, A SEATON, L J R MILNE, J A RAEBURN \\ From the Institute of Occupational Medicine and the Western General Hospital, Edinburgh
}

ABSTRACT An important feature of the microbicidal action of phagocytic cells is their ability to produce reactive oxygen intermediates. In an attempt to identify the mechanisms by which the fungus Aspergillus fumigatus resists normal host defences the effect of spores and spore diffusates of $A$ fumigatus on the production of superoxide anion and hydrogen peroxide by primed rodent phagocytic cells has been measured. For comparison we have used the non-pathogenic fungus Penicillium ochrochloron. Production of these reactive oxygen intermediates in response to $A$ fumigatus was significantly lower than that in response to $P$ ochrochloron. A similar reduction was achieved by diffusate prepared from freshly washed spores. The inhibitory component was of low molecular weight (less than 14000) and its effect was dose dependent. These results suggest that spores of $A$ fumigatus fail to trigger and also inhibit the production of reactive oxygen intermediates by phagocytic cells.

The opportunistic fungus Aspergillus fumigatus is of special interest to respiratory physicians because of its ability to cause several distinct pulmonary diseases. It may cause sensitisation in asthmatic subjects, leading in some instances to chronic symptoms and recurrent episodes of pulmonary infiltration. ${ }^{1}$ It may also colonise lung cavities to produce aspergillomas ${ }^{2}$ and invade lung tissue after infarction ${ }^{3}$ or influenza ${ }^{4}$ to produce a fatal necrotising pneumonia, or cause pulmonary and systemic infection in the immunosuppressed. ${ }^{5}$ The frequency with which it may be associated with lung disease suggests that the organism may be relatively resistant to the lung's defences. While spores of $A$ fumigatus occur commonly in the air, especially in winter, when dead leaves are available as a substrate, they are not among the most abundant. ${ }^{6}$ Moreover, studies of postmortem lung specimens have shown $A$ fumigatus to be present and viable more frequently than would be expected from its prevalence among the fungal spores normally found in the air, the aerospora, thus supporting the idea that it may have properties that protect it from the lung's defences. ${ }^{7}$ Such properties could ensure its survival in the lung long enough to initiate allergic and infective reactions in appropriate hosts.

Two factors that enhance the pathogenicity of $A$ fumigatus in man are the organisms' ability to grow

Address for reprint requests: Mrs MD Robertson, Institute of Occupational Medicine, 8 Roxburgh Place, Edinburgh EH8 9SU.

Accepted 27 August 1986 optimally at $37^{\circ} \mathrm{C}$ and the small spore size that enables it to penetrate to the alveolar level. To survive and germinate in the lung the spores must also be resistant to the phagocytic defences of the lung. In this paper we report the results of in vitro investigations of the interactions between $A$ fumigatus and phagocytic cells from rodents.

\section{Methods}

GENERAL PLAN

In an attempt to identify the mechanisms used by this fungus to resist killing by phagocytic cells we have examined the effects of spores and spore diffusate of $A$ fumigatus on the ability of the cell to produce oxidising agents (reactive oxygen intermediates) that can be used by the phagocyte for the destruction of microorganisms. ${ }^{8}$ We have compared the release by phagocytic cells from mice and rats of the reactive oxygen intermediates superoxide anion and hydrogen peroxide in response to challenge by $A$ fumigatus and by the non-pathogenic fungus Penicillium ochrochloron.

\section{PHAGOCYTIC CELLS}

Since resting phagocytic cells release minimal amounts of reactive oxygen intermediates, we used phagocytic cells obtained from mice and rats that had been previously primed in vivo with Corynebacterium parvum. This is a procedure that has been shown to increase the ability of phagocytic cells to release reactive oxygen intermediates, ${ }^{9}$ as well as generally to 
increase their microbicidal capacity. ${ }^{1011}$ For each experiment about $4 \times 10^{7}$ peritoneal exudate cells, which comprise $32 \%$ polymorphonuclear leucocytes and $63 \%$ macrophages, were harvested from six male C57B1/6 mice five days after intraperitoneal injection of $1.4 \mathrm{mg} C$ parvum (heat killed, Wellcome Biotechnology Ltd). About $2 \times 10^{7}$ bronchoalveolar lavage cells $(90 \%$ of which were polymorphonuclear leucocytes) were obtained from the lungs of male PVG rats 16 hours after intratracheal instillation of $0.7 \mathrm{mg}$ $C$ parvum.

FUNGAL SPORES AND DIFFUSATES

A single strain of $A$ fumigatus was isolated from the sputum of a patient with allergic bronchopulmonary aspergillosis. The strain of $P$ ochrochloron was IMI 61271. Spores of $A$ fumigatus and $P$ ochrochloron were obtained from cultures that had been grown for seven days at $29^{\circ} \mathrm{C}$ on malt agar. Spore suspensions containing only single spores were prepared in Hanks' balanced salt solution (HBSS) containing $0.01 \%$ bovine serum albumin (Sigma Chemical Co Ltd), after gentle homogenisation followed by filtration through nylon mesh to remove mycelial fragments and chains of spores. Spore counts were performed with improved Neubauer chambers. For the spore:cell experiments the spores were opsonised in 5\% autologous serum for 30 minutes at $37^{\circ} \mathrm{C}$, then washed in HBSS by centrifugation at $400 \mathrm{~g}$ for 10 minutes. The spores were then resuspended in HBSS and kept on ice until required. To obtain diffusates, spores were incubated at a concentration of $10^{8} / \mathrm{ml}$ in $\mathrm{HBSS}$ at $37^{\circ} \mathrm{C}$ for up to six hours. The soluble diffusates in the supernatant were passed through $0.22 \mu \mathrm{m}$ sterile filters. For the assay systems the diffusates were used at a 1:4 dilution in HBSS. The number of spores require to obtain this concentration of diffusate was equivalent to the number derived from a spore:cell ratio of 50:1.

\section{SUPEROXIDE ANION ASSAY}

Superoxide anion was measured according to the method of Johnston. ${ }^{12}$ Production of superoxide anion can be detected by the reduction of cytochrome $\mathrm{C}$, a reaction accompanied by an increase in spectrophotometric absorbance at a wave length of $550 \mathrm{~nm}$. The reaction mixture $(1.5 \mathrm{ml})$, containing $5 \times 10^{5}$ peritoneal exudate cells, $80 \mu \mathrm{mol}$ cytochrome $\mathrm{C}$ (Sigma), $2 \mathrm{mg} / \mathrm{ml}$ dextrose, and opsonised spores at a spore:cell ratio of $10: 1,50: 1$, and $100: 1$ or spore diffusates at a 1:4 dilution, was added to $30 \mathrm{~mm}$ Petri dishes (Falcon Plastics Ltd). For the diffusate doseeffect experiments a total reaction mixture of $1.3 \mathrm{ml}$ containing $2.5 \times 10^{5}$ bronchoalveolar cells was used. As an additional control, zymosan (Sigma), a cell wall extract of the yeast Saccharomyces cerevisiae and a potent trigger of superoxide anion release, was opsonised and added to the reaction mixture at $a \stackrel{.}{\Rightarrow}$ concentration of $1 \mathrm{mg} / \mathrm{ml}$. To determine the portion of $\stackrel{\vec{\rho}}{\stackrel{F}{9}}$ reduced cytochrome $\mathrm{C}$ that could be inhibited by superoxide dismutase, identical dishes with the addi- 음 tion of superoxide dismutase (Sigma) $25 \mu \mathrm{g} / \mathrm{ml}$ were $\frac{\bar{c}}{7}$ prepared at the same time. All experiments were set up $\stackrel{\mathbb{\Omega}}{\Omega}$ in triplicate and the mixtures incubated at $37^{\circ} \mathrm{C}$ for $\stackrel{\circ}{\circ}$ two hours. The supernatants were harvested and the peak absorbance at $550 \mathrm{~nm}$, a measure of reduced cytochrome $\mathrm{C}$, was determined by using the scan $\overrightarrow{\vec{\omega}}$ mode on a spectrophotometer (SP8/400 Pye Unicam). The reduction of cytochrome $\mathrm{C}$ is not specific for $\overrightarrow{\vec{x}}$ superoxide anion. The required specificity is achieved by the use of superoxide dismutase, for which superoxide anion is the only known substrate. Therefore $\overrightarrow{\vec{\theta}}$ the assay was run with and without superoxide dismutase and only the portion of the reduced cyto- $\frac{}{工}$ chrome $\mathrm{C}$ that could be inhibited by superoxide dis- $\overrightarrow{\vec{c}}$ mutase was used to estimate the nanomols of superoxide anion released.

\section{HYDROGEN PEROXIDE ASSAY}

Hydrogen peroxide was measured according to the method of Pick and Keisari. ${ }^{13}$ The assay is based on the horseradish peroxidase mediated oxidation of phenol red by hydrogen peroxide, which results in the formation of a compound showing increased absorbance at $610 \mathrm{~nm}$. The reaction mixture $(1 \mathrm{ml})$, contain- $\frac{\not}{\mathbb{Q}}$ ing $5 \times 10^{5}$ peritoneal exudate cells, $10 \mathrm{nmol}$ phenol $\stackrel{\varrho}{\longrightarrow}$ red solution (Sigma), $\mathrm{NaCl}(140 \mathrm{nmol})$, dextrose을 $(5.5 \mathrm{nmol})$, and horseradish peroxidase $(50 \mu \mathrm{g} / \mathrm{ml})$ (Sigma) in $10 \mathrm{nmol}$ potassium phosphate buffer, and opsonised spores at a spore:cell ratio of 10:1, 25:1, and $50: 1$ or spore diffusates at a 1:4 dilution was added to $30 \mathrm{~mm}$ Petri dishes. For the diffusate dose-effect $\frac{0}{2}$ experiments a total reaction mixture of $1.3 \mathrm{ml}$ containing $2.5 \times 10^{5}$ bronchoalveolar cells was used. As an 3 . additional control, opsonised zymosan was added to the reaction mixture at a concentration of $1 \mathrm{mg} / \mathrm{ml}$. $\frac{\text { 잉 }}{3}$ All experiments were set up in triplicate and incubated at $37^{\circ} \mathrm{C}$ for two hours. The supernatants were then 5 harvested and alkalised by the addition of $30 \mu \mathrm{l}$ of $\frac{D}{O}$ $1 \mathrm{~N} \mathrm{NaOH}$. The absorbance of the solution at $610 \mathrm{~nm}=$ was measured in a spectrophotometer and converted $/$ to hydrogen peroxide equivalent by means of a stan- $N$ dard curve.

TECHNIQUES USED TO DETECT A POSSIBLE SCAVENGING EFFECT OF DIFFUSATES ON REACTIVE OXYGEN INTERMEDIATES

To test for a possible scavenging effect of the diffusates on reactive oxygen intermediates, we used: (a) a cell free superoxide anion generation system gen- $\overrightarrow{\mathbb{D}}$ erally based on the method described by Rosen and $\frac{\widehat{P}}{\mathbb{D}}$ Klebanoff. $^{14}$ Superoxide anion was generated by incubating xanthine oxidase $20 \mu \mathrm{g} / \mathrm{ml}$ (Sigma) with 
acetaldehyde $40 \mathrm{nmol}$ for five minutes at $37^{\circ} \mathrm{C}$. This resulted in the generation of about $6 \mathrm{nmol}$. To this superoxide anion $1 \mathrm{ml}$ of the following was added: $(a)$ HBSS (control); (b) superoxide dismutase $(25 \mu \mathrm{g})$, which catalyses the destruction of superoxide anion to oxygen and hydrogen peroxide; (c) diffusate (1:4 dilution). Each of the three treatments was set up in triplicate and incubated for 10 minutes at $37^{\circ} \mathrm{C}$. The reaction mixture, used to detect superoxide anion (described above), was then added and after a further incubation for 10 minutes at $37^{\circ} \mathrm{C}$ the absorbance at $550 \mathrm{~nm}$ was measured; (ii) hydrogen peroxide (Sigma) was diluted to give concentrations ranging from 1 to $20 \mathrm{nmol}$. To the hydrogen peroxide $1 \mathrm{ml}$ of the following was added: (a) HBSS (control); $(b)$ catalase (Sigma) $100 \mu \mathrm{g} / \mathrm{ml}$, an enzyme that catalyses the degradation of hydrogen peroxide to oxygen and water; and $(c)$ diffusate (1:4 dilution). Each of the three treatments was prepared in duplicate and incubated for 30 minutes at $37^{\circ} \mathrm{C}$. The reaction mixture used to detect hydrogen peroxide (described above) was added to the tubes, which were then incubated for a further 30 minutes at $37^{\circ} \mathrm{C}$. The absorbance of the mixture was read at $610 \mathrm{~nm}$.

\section{DIFFUSATE DIALYSIS}

To determine whether the active constituent of the diffusate was of low molecular weight the diffusate was dialysed against HBSS for 16 hours at $4^{\circ} \mathrm{C}$. As we had observed that the activity of the diffusate decreases on storage at $4^{\circ} \mathrm{C}$, an aliquot of the diffusate was put into dialysis tubing and kept in a sealed tube for 16 hours at $4^{\circ} \mathrm{C}$, as a control.

\section{DIFFUSATE RELEASE}

To discover at what stage the diffusates were released into the supernatant we added spores $\left(10^{8} / \mathrm{ml}\right)$ to HBSS, divided this suspension into three aliquots, and carried out the following treatments. (1) The spores were incubated for two minutes and immediately removed and the supernatants filtered ("two minutes incubation (washings)" in table 4). (2). The washed spores were resuspended in HBSS and incubated for three hours at $37^{\circ} \mathrm{C}$ before the spores were spun out to obtain the supernatant, which was filtered ("washed + three hours incubation"). (3) The spores were incubated in HBSS for 3 hours and the supernatant removed then filtered ("three hours incubation").

\section{CELL VIABILITY}

To determine whether the spore diffusates were having a toxic effect on the cells, $5 \times 10^{5}$ cells were incubated for two hours at $37^{\circ} \mathrm{C}$ in $1 \mathrm{ml}$ of control HBSS or spore diffusates (1:4 dilution). After this time the percentage viability was determined by the trypan blue (Gibco) exclusion method.
EXPERIMENTAL DESIGN AND STATISTICAL ANALYSIS

Each experiment was carried out in triplicate and performed on two to five separate occasions. For individual experiments a different group of animals and spores or spore diffusates prepared from fresh cultures were used. Therefore day to day variation in spontaneous release of reactive oxygen intermediates and strength of diffusates did occur. The statistical analyses were designed to take into account this variation between experiments and treatments so that the analyses of treatment effects would be independent of interexperimental variation. Initially the raw data were subjected to analysis of variance with a randomised block design in which each day/experiment constituted a block. Student's $t$ tests were used to compare treatment means, using the residual error obtained from the analysis of variance.

\section{Results}

EFFECTS OF SPORES ON RELEASE OF SUPEROXIDE ANION

C parvum stimulated mouse peritoneal exudate cells released significantly less superoxide anion $(\mathrm{p}<$ 0.001 ) in response to spores of $A$ fumigatus than in response to zymosan or $P$ ochrochloron (table 1). Both zymosan and $P$ ochrochloron were associated with a release of superoxide anion that was significantly greater than the spontaneous release by cells $(p<$ 0.001 ). When the results from the individual spore:cell ratios were combined, $P$ ochrochloron was seen to stimulate an increase in superoxide anion release of about $50 \%$, while zymosan, a potent trigger of superoxide anion, stimulated a three fold increase.

EFFECTS OF SPORES ON RELEASE OF HYDROGEN PEROXIDE

Both zymosan and $P$ ochrochloron slightly reduced the spontaneous release of hydrogen peroxide by $C$ par-

Table 1 Effect of opsonised zymosan and opsonised fungal spores on the release of superoxide anion by peritoneal exudate cells

\begin{tabular}{lll}
\hline Treatment & Spore : cell ratio & $\begin{array}{l}\text { Superoxide anion } \\
(\text { nmol : mean }(S E M))\end{array}$ \\
\hline HBSS* & - & $12 \cdot 89(1 \cdot 20)$ \\
Zymosan & - & $41.6(0 \cdot 60)$ \\
A fumigatus & $10: 1$ & $12 \cdot 06(0 \cdot 20)$ \\
A fumigatus & $50: 1$ & $11.07(0 \cdot 45)$ \\
A fumigatus & $100: 1$ & $11 \cdot 09(0 \cdot 84)$ \\
$P$ ochrochloron & $10: 1$ & $14 \cdot 62(1.60)$ \\
$P$ ochrochloron & $50: 1$ & $20 \cdot 12(1 \cdot 23)$ \\
$P$ ochrochloron & $100: 1$ & $18.4(1 \cdot 70)$ \\
\hline
\end{tabular}

*Treatment with Hanks' balanced salt solution (HBSS) gives a measure of the spontaneous release. 
Table 2 Effect of opsonised zymosan and opsonised fungal spores on the release of hydrogen peroxide by peritoneal exudate cells

\begin{tabular}{lll}
\hline Treatment & Spore : cell ratio & $\begin{array}{l}\text { Hydrogen peroxide } \\
(\text { nmol:mean }(S E M))\end{array}$ \\
\hline HBSS* & - & $10 \cdot 19(1 \cdot 57)$ \\
Zymosan & - & $9 \cdot 53(1 \cdot 53)$ \\
A fumigatus & $10: 1$ & $8 \cdot 63(1.41)$ \\
A fumigatus & $25: 1$ & $6 \cdot 80(0 \cdot 35)$ \\
A fumigatus & $50: 1$ & $5 \cdot 15(0 \cdot 87)$ \\
$P$ ochrochloron & $10: 1$ & $8 \cdot 63(1 \cdot 18)$ \\
$P$ ochrochloron & $50: 1$ & $8 \cdot 16(1.88)$ \\
\hline
\end{tabular}

*Treatment with Hanks' balanced salt solution (HBSS) gives a measure of the spontaneous release.

vum stimulated mouse peritoneal exudate cells (table 2). A fumigatus produced a reduction of hydrogen peroxide release and this effect was more pronounced with increasing spore:cell ratios. When the results from the individual spore:cell ratios were combined the release of hydrogen proxide was significantly lower in response to $A$ fumigatus ( $\mathrm{p}<$ $0.001)$ than to zymosan or $P$ ochrochloron.

EFFECTS OF SPORE DIFFUSATES ON RELEASE OF REACTIVE OXYGEN INTERMEDIATES

To examine the possibility that $A$ fumigatus may produce a substance that has a direct effect on cellular production of reactive oxygen intermediates, we measured the effect of diffusates obtained from spores of $A$ fumigatus and $P$ ochrochloron on the spontaneous release of reactive oxygen intermediates from $C$ parvum stimulated mouse peritoneal exudate cells. Diffusates from $A$ fumigatus greatly reduced $(p<$
$0.001)$ the spontaneous release of superoxide anion $\stackrel{x}{.}$

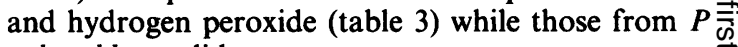
ochrochloron did not.

Using bronchalveolar lavage cells obtained from $\frac{\mathrm{C}}{5}$ rats whose lungs had been treated with $C$ parvum, we $\overline{\bar{c}}$ found that this inhibitory effect was strikingly $\vec{D}$ dependent on the concentration of diffusate (fig 1).

STUDIES OF THE DIFFUSATE FROM SPORES OF A FUMIGATUS

(1) Viability studies established that the spore $\vec{\sigma}$ diffusates were not having a toxic effect on the cells, as $\overrightarrow{\vec{*}}$ the percentage viability of the cells after an incubation $\times$ period of two hours in spore diffusate was the same as $\stackrel{\vec{N}}{\vec{H}}$ that found with control HBSS ( $>95 \%$ viable).

(2) To find out at what stage the diffusates were $\vec{\bullet}$ released into the supernatant, we looked at the effect? of time on the diffusion, from spores of the factor that inhibited reactive oxygen intermediates production.

Table 3 Effect of spore diffusates on the spontaneous release of superoxide anion and hydrogen peroxide by peritoneal exudate cells

\begin{tabular}{|c|c|c|}
\hline Treatment & $\begin{array}{l}\text { Superoxide anion } \\
(\text { nmol: mean }(S E M))\end{array}$ & $\begin{array}{l}\text { Hydrogen peroxide } \\
(\text { nmol: mean }(S E M))\end{array}$ \\
\hline \multirow{3}{*}{$\begin{array}{l}\text { HBSS* } \\
\text { A fumigatus } \\
\text { diffusates } \\
P \text { ochrochloron } \\
\text { diffusates }\end{array}$} & $14 \cdot 38(0 \cdot 26)$ & $18.82(1.63)$ \\
\hline & $6.73(0.43)$ & $4 \cdot 16(0 \cdot 52)$ \\
\hline & $14.40(0 \cdot 67)$ & $19 \cdot 43(2 \cdot 25)$ \\
\hline
\end{tabular}

*Treatment with Hanks' balanced salt solution (HBSS) gives a्ठ measure of the spontaneous release.

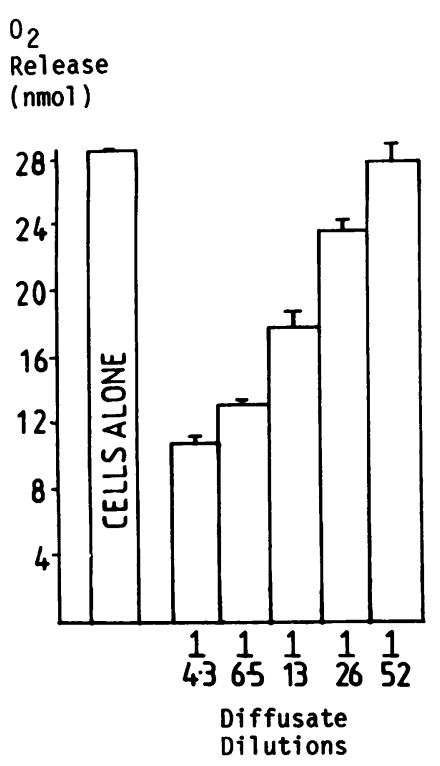

$\mathrm{O}_{2}$ (nmol)
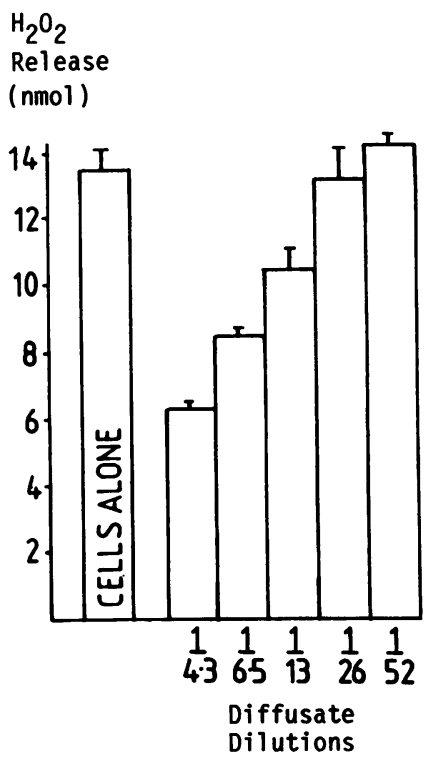

Effect of increasing dilution of spore diffusates of Aspergillus fumigatus on the spontaneous release of superoxide anion $\left(\mathrm{O}_{2}^{-}\right)$ and hydrogen peroxide $\left(\mathrm{H}_{2} \mathrm{O}_{2}\right)$ by $\mathrm{N}$ phorbol myristate acetate triggered Corynebacterium parvum induced rat bronchoalveolar lavage cells $\left(2.5 \times 10^{5}\right.$ cells $)$ when compared with the cells alone (two hour incubation period): means with standard deviations. 
Table 4 shows that washings ( 2 min incubation) from the spores significantly reduced release of reactive oxygen intermediates $(\mathrm{p}<0.001)$ by $C$ parvum stimulated mouse peritoneal exudate cells. Therefore the diffusate is released immediately the spores are put into liquid. In addition, the spores, once washed, continue to release the diffusate. The longer the spores were incubated the greater was the inhibitory capacity of the diffusate.

(3) To examine whether the diffusate was affecting production of reactive oxygen intermediates by the phagocytic cell or scavenging the reactive oxygen intermediates once produced, or both, we looked at the effect of adding the diffusate at a 1:4 dilution to a cell free superoxide anion generation system and to hydrogen peroxide. We found that the amount of superoxide anion present after the addition of the diffusates $(5.84 \mathrm{nmol})$ was the same as that found after the addition of control HBSS $(5.86 \mathrm{nmol})$. The addition of superoxide dismutase (which is used in the conversion of superoxide anion to hydrogen peroxide), however, removed the superoxide anion from the system. This result confirmed that the diffusate does not scavenge superoxide anion as generated by the xanthine oxidase acetaldehyde system. Similarly, we found that the diffusates did not scavenge hydrogen peroxide. The addition of control HBSS to a system containing hydrogen peroxide results in a linear increase in absorbance at $610 \mathrm{~nm}$ (a measure of hydrogen peroxide in the system) with increasing concentration of hydrogen peroxide $(1-20 \mathrm{nmol})$. The addition of the diffusate to the hydrogen peroxide resulted in an increase in absorbance at $610 \mathrm{~nm}$, the same as that given with HBSS. When catalase, an enzyme that breaks down hydrogen peroxide, was added to the system, however, no increase in absorbance at $610 \mathrm{~nm}$ was obtained.

(4) The inhibitory effect of the diffusate on release of reactive oxygen intermediates by $C$ parvum stimulated mouse peritoneal exudate cells was removed by dialysis (table 5), indicating that the molecular weight of the active substance in the diffusate is less than 14000 daltons.

\section{Discussion}

The key role played by phagocytic cells in the eradication of microorganisms is well documented.$^{815-17}$ Several studies have, however, reported apparently conflicting results concerning the interaction of these cells with $A$ fumigatus. Rabbit alveolar macrophages ${ }^{18}$ and human blood monocytes ${ }^{19}$ have been found to be capable of killing $A$ fumigatus in vitro. Schaffner et al, ${ }^{20}$ who compared natural immunity to $A$ fumigatus in vivo with the actions of phagocytes against the organisms in vitro, suggested that
Table 4 Effect of time on the diffusion from A fumigatus spores of activity that inhibits the production of superoxide anion and hydrogen peroxide by peritoneal exudate cells

\begin{tabular}{lll}
\hline Treatment & $\begin{array}{l}\text { Superoxide anion } \\
(\text { nmol:mean }(S E M))\end{array}$ & $\begin{array}{l}\text { Hydrogen peroxide } \\
(\text { nmol:mean }(S E M))\end{array}$ \\
\hline $\begin{array}{l}\text { HBSS* } \\
\text { 2 min incubation } \\
\text { (washings) }\end{array}$ & $13.43(0.42)$ & $13.9(0.69)$ \\
$\begin{array}{l}\text { washed spores }+ \\
\text { 3h incubation }\end{array}$ & $6.93(0.25)$ & $8.6(0.36)$ \\
3h incubation & $\begin{array}{l}5.13(0.18) \\
4.77(0.15)\end{array}$ & $\begin{array}{l}4.43(0.14) \\
3.3(0.06)\end{array}$ \\
\hline
\end{tabular}

*Treatment with Hanks' balanced salt solution (HBSS) gives a measure of the spontaneous release.

Table 5 Effect of dialysis on the capacity of the diffusate to inhibit the production of superoxide anion and hydrogen peroxide

\begin{tabular}{lll}
\hline Treatment & $\begin{array}{l}\text { Superoxide anion } \\
(\text { nmol:mean }(S E M))\end{array}$ & $\begin{array}{l}\text { Hydrogen peroxide } \\
(\text { nmol:mean }(S E M))\end{array}$ \\
\hline HBSS* & $12.98(1.38)$ & $21.3(2.06)$ \\
Diffusates & $5.65(0.57)$ & $8.75(1.07)$ \\
$\begin{array}{l}\text { Diffusates incubated } \\
4^{\circ} \mathrm{C} 18 \mathrm{~h}\end{array}$ & $9.95(1.28)$ & $13.86(0.38)$ \\
$\begin{array}{l}\text { Diffusates dialysed } \\
4^{\circ} \mathrm{C} 18 \mathrm{~h}\end{array}$ & $13.76(1.69) \dagger$ & $25.6(1.82) \dagger$ \\
\hline
\end{tabular}

*Treatment with Hanks' balanced salt solution (HBSS) gives a measure of the spontaneous release.

tp $<0.0001$ for incubated versus dialysed diffusate.

monocytes may be concerned with killing spores while polymorphonuclear leucocytes may be responsible for the eradication of hyphae, apparently in the absence of a specific immume response. Other workers, however, have been unable to show either in vitro killing of $A$ fumigatus by human monocytes or polymorphonuclear leucocytes ${ }^{21}$ or killing in vivo by mouse or rabbit alveolar cells. ${ }^{22} 23$ Nevertheless, the potential importance of reactive oxygen intermediates, and of hydrogen peroxide in particular, in the eradication of spores and hyphae has been demonstrated with cell free systems of myeloperoxidase-hydrogen peroxide-halide ${ }^{24}$ and ferrous iron-hydrogen peroxide-halide, ${ }^{25}$ both of which are capable of killing $A$ fumigatus.

Our study, using phagocytic cells from mice and rats, shows that spores of $A$ fumigatus fail to trigger an increase in superoxide anion release while zymosan and control spores of $\boldsymbol{P}$ ochrochloron trigger a substantial increase. This suggests that spores of $A$ fumigatus are failing to trigger the primary component of the "respiratory burst." The normal sequence of events in the release of reactive oxygen intermediates by phagocytic cells is the production of superoxide anion, which can either spontaneously or with the help of superoxide dismutase form hydrogen peroxide. $^{16}$ If, as we have found, $A$ fumigatus does not trigger an increased release of detectable amounts of 
superoxide anion it might be expected that hydrogen peroxide concentrations would also be low, unless rapid dismutation of superoxide anion were occurring. We have shown that spores of $A$ fumigatus, as well as failing to trigger superoxide anion release, also at a spore:cell ratio of $25: 1$ and above suppress hydrogen peroxide production by comparison with either spores of $\boldsymbol{P}$ ochrochloron or zymosan. The responses of stimulated peritoneal exudate cells to triggering by zymosan with the release of increased amounts of superoxide anion without an increase in the release of hydrogen peroxide have been previously reported both from this laboratory ${ }^{9}$ and by others. ${ }^{26}$ In general, the release of reactive oxygen intermediates in response to spores of the control fungus $P$ ochrochloron parallels the response to zymosan.

We have previously noted that spores of $A$ fumigatus become attached to phagocytic cells ${ }^{27}$ in vitro and in vivo; it is therefore interesting that binding of spores to the cell does not trigger release of reactive oxygen intermediates. The studies reported here explain this to the extent that we have shown that the spores release a substance that interferes with the production of those oxidants, and that this substance is released immediately the spores are put into suspension. Furthermore, it continues to be released after the spores have been washed and is of low (less than 14000 daltons) molecular weight. Thus the physical interactions of spores of $A$ fumigatus with the phagocytic cells appear to produce an immediate respiratory burst similar to that produced by cells alone. The enhanced production of superoxide anion seen in respose to the controls $P$ ochrochloron and zymosan is, however, suppressed in response to release of the diffusate by $A$ fumigatus. These findings are consistent with our previous observations that, in vitro, a large number of spores of $A$ fumigatus appear to remain bound to the surface of phagocytic cells without becoming fully ingested. ${ }^{27}$ This potential antiphagocytic effect of $\boldsymbol{A}$ fumigatus has also recently been described by Müllbacher et al, ${ }^{28}$ who found that a metabolite called gliotoxin, isolated from three day culture supernatants of $A$ fumigatus, had an inhibitory effect on the phagocytosis of carbon particles by mouse peritoneal exudate cells. The difference between this gliotoxin and the diffusate described in the present study is that the gliotoxin could not be isolated until the spores had been in culture for at least three days, at which time mycelial growth would be abundant. In contrast, the diffusate described here diffuses from the respirable sized spores as soon as they are put into suspension. The quick release of the diffusate from the spores suggests that it may be located on or close to the surface of the spore. Possibly the diffusate is the first mechanism by which the spore reduces the efficiency of the phagocyte while the glio- toxin, which is produced once germination has taken $\Rightarrow$ place, may be a second line of antiphagocyte defence $\stackrel{\mathcal{W}}{+}$ used by $A$ fumigatus to establish itself and remain $\bar{C}$ within the lung.

Our findings may also be relevant to the results of $\frac{\overline{\bar{c}}}{5}$ those studies that have indicated that the resistance of $\mathbb{D}$ some microorganisms to killing is inversely related to the phagocytic cell's ability to release reactive oxygen $\overrightarrow{-}$

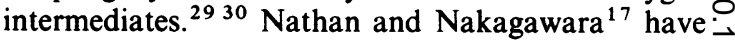
postulated that the pathogenicity of microorganisms $\vec{\omega}$ may, in general, be related to their possession of antioxidant defence and to their capacity to avoid trig- $\vec{x}$ gering the release of reactive oxygen intermediates by macrophages. A fumigatus would appear from our study to have evolved such mechanisms and this may $\overrightarrow{0}$ in part be responsible for its pathogenicity to the lungs 을

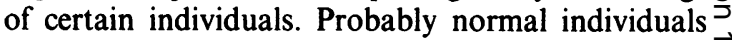
have sufficient resources within their host defence net- $\vec{c}$ work to overcome and remove these spores. At the other end of the scale $A$ fumigatus can overcome the defective host defences of immunocompromised individuals, resulting in invasive aspergillosis. Perhaps $\vec{\oplus}$ some patients with asthma lie in the middle of this $\stackrel{\infty}{\checkmark}$ hypothetical scale, where the fungus, although con- 7 trolled to a certain degree, is not efficiently removed and therefore remains within the lung, thus enabling it to provoke an immune response with the resultant allergic reactions.

We would like to thank Miss HPR Collins and Mr W $\overline{\overline{0}}$ McLaren for statistical assistance. This work is supported by a grant from the Asthma Research Council.

\section{References}

1 McCarthy DS, Pepys J. Allergic bronchopulmonary aspergillosis. Clinical immunology: (1) clinical features. Clin Allergy 1971;1:261-86.

2 Crofton J, Douglas A. Respiratory diseases. 3rd ed. Oxford: Blackwell Scientific Publications, 1981:332. 윽

3 Buchanan DR, Lamb D. Saprophytic invasion of $D$ infarcted pulmonary tissue by Aspergillus species.음 Thorax 1982;37:693-8.

4 McLeod DT, Milne LJR, Seaton A. Successful treatmento̊ of invasive pulmonary aspergillosis complicating influenza A. Br Med J 1982;285:1166-7.

5 Warren RE, Warnock DW. Clinical manifestations and management of aspergillosis in the compromised patient. In: Warnock DW, Richardson MD, eds. Fun 6 gal infection in the compromised host. Chichester: John Wiley and Sons, 1982:119-53.

6 Mullins J, Harvey R, Seaton A. Sources and incidence of airborne Aspergillus fumigatus (Fres). Clin Allergyo 1976;6:209-17.

7 Mullins J, Seaton A. Fungal spores in lung and sputum. $\frac{\stackrel{\rho}{\Phi}}{2}$ Clin Allergy 1978;8:525-33.

8 Babior BM. Oxygen-dependent microbial killing by 
phagocytes. $N$ Engl J Med 1978;290:659-68.

9 Donaldson K, Slight J, Bolton RE. Increased release of hydrogen peroxide anion from asbestos primed macrophages. Inflammation 1985;9:139-48.

10 Glasgow LA, Fischbach J, Bryant SM, Kern ER. Immunomodulation of host resistance to experimental viral infections in mice: Effects of Corynebacterium acnes, Corynebacterium parvum and bacille Calmette-Guérin. J Infect Dis 1977;135:763-70.

11 Swartzberg JE, Krahenbuhl JL, Remington JS. Dichotomy between macrophage activation and degree of protection against Listeria monocytogenes and Toxoplasma gondii in mice stimulated with Corynebacterium parvum. Infect Immun 1975;12:1037-43.

12 Johnston RB. Secretion of superoxide anion. In: Adams DO, Edelson PJ, Koren H, eds. Methods for studying mononuclear phagocytes. London: Academic Press, 1981:489-97.

13 Pick E, Keisari Y. A simple colorimetric method for the measurement of hydrogen peroxide produced by cells in culture. Immunol Meth 1980;38:161-70.

14 Ayars GH, Altman LC, Rosen H, Doyle T. The injurious effect of neutrophils on pneumocytes in vitro. Am Rev Respir Dis 1984;130:964-73.

15 Iyer GYN, Islam MF, Quastel JH. Biochemical aspects of phagocytosis. Nature 1961;192:535-41.

16 Klebanoff SJ. Oxygen intermediates and the microbicidal event. In: Van Furth R, ed. Mononuclear phagocytes. The Hague: Martinus Nijhoff, 1980:1105-37.

17 Nathan CF, Nakagawara A. Role of reactive oxygen intermediates in macrophage killing of intracellular pathogens: A review. In: Mizuno D, Cohn ZA, Takeya $\mathrm{K}$, Ishida $\mathrm{N}$, eds. Self-defence mechanisms-role of macrophages. Japan: University of Tokyo Press/Elsevier Biomedical Press, 1982:279-94.

18 Kurup VP. In vitro infection of rabbit alveolar macrophages with Aspergillus spores. Asbtracts of the annual meeting of the American Society of Microbiology. 1981;81:317.

19 Diamond RD, Huber E, Haudenschild CC. Mechanisms of damage to Aspergillus hyphae by human monocytes
[Abstract]. Clin Res 1981;29:383A.

20 Schaffner A, Douglas H, Braude A. Selective protection against conidia by mononuclear and against mycelia by polymophonuclear phagocytes in resistance to Aspergillus. J Clin Invest 1982;69:617-31.

21 Lehrer RI, Jan RG. Interation of Aspergillus fumigatus spores with human leukocytes and serum. Infect Immun 1970;1:345-50.

22 White LO. Germination of Aspergillus fumigatus conidia in the lungs of normal and cortisone-treated mice. Sabouraudia 1977;15:37-41.

23 Kurup VP. Interaction of Aspergillus fumigatus spores and pulmonary alveolar macrophages of rabbits. Immunobiology 1984;166:53-61.

24 Diamond RD, Clark RA. Damage to Aspergillus fumigatus and Rhizopus oryzae hyphae by oxidative and non-oxidative microbicidal products of human neutrophils in vitro. Infect Immun 1982;38:487-95.

25 Levitz SM, Diamond RD. Killing of Aspergillus fumigatus spores and Candida albicans yeast phase by the iron-hydrogen peroxide-iodide cytotoxic system: comparison with the myeloperoxidase-hydrogen peroxideiodide system. Infect Immun 1984;43:1100-2.

26 Karnovsky ML, Badwey JA. Determinants of the products of active oxygen species by granulocytes and macrophages. J Clin Chem Clin Biochem 1983;21:545-53.

27 Robertson MD, Raeburn JA, Gormley IPG, Seaton A. Do phagocytic cells ingest spores of Aspergillus fumigatus? [Abstract]. Thorax 1985;40:237.

28 Müllbacher A, Waring P, Eichnar RD. Identification of an agent in cultures of Aspergillus fumigatus displaying anti-phagocytic and immunomodulating activity in vitro. J Gen Microbiol 1985;131:1251-8.

29 Murray HW, Juangbhanich CW, Nathan CF, Cohn ZA. Macrophage oxygen-dependent antimocrobial activity. II. The role of oxygen intermediates. $J$ Exp Med 1979;150:950-64.

30 Sasada M, Johnston RB. Macrophages microbicial activity correlation between phagocytosis associated oxidative metabolism and the killing of Candida by macrophages. J Exp Med 1980;152:85-98. 